cent. But, as may be seen in the table, a piece from another stock gave a different amount of leakage. The same holds good for platinum, one specimen tried being twice as active as another. It was found that ignition did not affect the radio-activity of a given specimen of platinum.

In order to compare the activity of the substances mentioned above with that of uranium, a small crystal of uranium nitrate, measuring $12 \times 4 \mathrm{~mm}$., was cemented to the inside of one of the cylinders; the rate of leak due to it was found to be thirteen times that due to the most active cylinder of platinum. The area of the uranium was only $1 / 240$ th part that of the platinum, so that its activity for an equal area would be no less than 3000 times greater. It is possible that the radioactivity of ordinary materials may be due to traces of the more active substances. This would explain the varying activities of different samples of the same metal: Only an infinitesimal proportion of radium would be required. Radium is 100,000 times more active than uranium, and uranium 3000 times more active than the most active common material that I have experimented with. So that one part of radium in three hundred million would suffice to account for the observed effects.

R. J. Strutr.

\section{OYSTERS AND TYPHOII) FEVER.}

$T H E$ recent outbreaks of typhoid fever at Winchester and at Southampton have again directed public attention to the risk of typhoid infection due to the laying down of edible forms of shell-fish in sewage. polluted waters.

So long ago as 1895 , in a report made by Dr. Bulstrode to the Local Government Board, it was pointed out that few of the oyster layings, fattening beds or storage ponds round the English and Welsh coasts could be regarded as free from possible sewage contam. ination. In consequence of this report, the Local Government Board in 1899 introduced a Bill providing that the various county and borough councils should ascertain from time to time the sanitary conditions of the oyster layings and empowering these bodies to take action if sewage pollution were proved. This Bill, which dealt only with oysters, after having been read a second time, was withdrawn. Apparently nothing has since been done, matters have been allowed to drift, and in consequence several outbreaks of disease have occurred, with loss of valuable lives, and an important industry is threatened with temporary ruin.

In 1901, the medical officer of health for Westminster reported on certain cases of typhoid fever seemingly due to contaminated cockles, from some of which a bacillus, having all the characters of the typhoid bacillus, was isolated at the Jenner Institute of Preventive Medicine.

Dr. Nash, the medical officer of health for Southend. on-Sea, reported upon the incidence of typhoid fever in that borough during 1901, and found that in no less than twenty-one out of thirty-seven cases of the disease there was a history of the eating of shell-fish (generally oysters and cockles) within a month of the onset of the disease, i.e. within the incubation period. From a report by Dr. Allan, medical officer of health for the City of Westminster, mussels also seem to be implicated.

Attacks of illness, attributable to the eating of shellfish, in the Borough of Wandsworth and the City of Westminster having been brought to the notice of the Corporation of the City of London, the last-named body has taken action. The responsibility of the City Corporation in this matter is great, for not only are the majority of the cockles and many of the oysters implicated exposed for sale in the City, but the former shellfish is mostly obtained and relaid within the City's NO. 1738 , vOL. 67$]$ jurisdiction. The City Corporation has therefore caused a number of samples to be bacterioscopically examined by Dr. Klein, and his reports show that a larger or smaller proportion of the samples examined from every district shows evidence of sewage contamination, ' and from certain cockles the typhoid bacillus has actually been isolated.

The question then arose as to dealing with an obviously infected and dangerous source of food supply. Under the Public Healih (London) Act I89I, it is possible to obtain a justice's order to destroy such unwholesome food, but the necessary examination to establish the fact involves a lapse of several days, and before the results of such examination could be known, the whole quantity of the sample implicated would have been consumed. In the circumstances, the facts were reported to the Worshipful Company of Fishmongers, which has extensive powers over the fishing industry throughout the country, and the Company's inspectors are now engaged in a survey of the various sites of the shell-fish fisheries and are taking steps to stop the sale of contaminated molluscs.

lt might have been thought ihat sea-water would be prejudicial to the typhoid bacillus, but such does not appear to be the case. The experiments of Dr. Klein and of Prof. Boyce have shown that although the organism does not multiply, it retains its vitality in seawater for at least three or four weeks. In the infected oyster it lives for two to three weeks or more, and even when washed in pure running sea-water, the infective properties may be retained for several days.

As regards cockles, these are "cooked" before con. sumption, and thorough cooking would be fatal to the typhoid bacillus. But it seems that the "cooking" of cockles is a very perfunctory process, and consists in simply plunging nets filled with the molluscs into boiling water, so that many might (and obviously do) escape the full action of the heat; actual boiling renders them tough and uneatable.

Legislative enactments and periodical inspections are obviously necessary to protect the public from the risk of infection from sewage contaminated shell-fish, and should be welcomed by the merchants and their employés whose livelihood depends upon this important industry. So far back as 1894 , the value of the oysters alone landed by English dredgers in that year amounted to $84,271 l$.

R. T. HEWLETT.

\section{MR. MARCONI AND THE POST OFFICE.}

THE fact that the message from the King to President Roosevelt, in reply to the latter's wireless telegram of greeting, had to be sent to America by cable occasioned at the time much comment and correspondence in the daily papers on the attitude of the Post Office towards Mr. Marconi; the subject cropped up again last week on the return of Mr. Marconi to this country after his successful expedition to America. There is some little difficulty in ascertaining the real state of the case, as two or three different explanations have been put forward in the papers, but the truth of the matter seems to be precisely what we stated in our notes columns four weeks ago. In an interview with a representative of the Daily Express, Mr. Marconi made the following statements:-

"We asked the Post Office authorities whether they would allow us to connect our station at Poldhu by wire with Mullion-at our own expense, mind you-but they refused absolutely and entirely."

"The message (that from the King) was not received at our offices until after Mullion Post Office had closed for the night, and one cannot very well keep a King's message 
lying about for twelve hours. I think it would have been much more discourteous to the King to have kept his message waiting for a day than it was to send it by cable."

It seems, therefore, that the King, having sent his reply to the $I$.ondon office of the IVireless Telegraph Company, the company could not send it on to Poldhu for transmission to America on account of the fact that it was impossible at night to wire from London to Poldhu: thev were compelled, in consequence, to send the message by cable, the cable companies possessing the advantage: of a direct connection between the Post Office lines and the shore ends of their cables. It is a similar connection for which the Marconi Company asks and offers to pay, but which the Post Office declines to grant.

In these circumstances it is not surprising that $\mathrm{Mr}$. Marconi's feelings towards the Post Office are rather bitter, and that he proposes to make no further additions to the Poldhu Station until the authorities have decided what they intend to do. He now proposes to go to Italy and build a huge station there, probably at Rome, partly, no doubt, because, as he says, "Abroad I can get everything I want. Here in England I can get nothing." "This is a little sweeping, for all England has not been so backward in supporting Mr. Marconi's enterprise as the officials of the Post Office. The attitude of the Post Office, however, certainly seems inexcusable, and we do not see by what reasonable arguments it can be supported. It has been urged that, until Mr. Marconi has been able to convince a jury of Government officials and independent experts that his system is capable of satisfying stringent tests of trustworthiness for a definite period under definite conditions, the Post Office is fully justified in withholding its recognition and support. This argument seems to us unsound. If the Post Office is not satisfied that Transatlantic wireless telegraphy is trustworthy, let it, by all means, send its own messages by cable; but is this any reason why the man in the street-or the King-who wishes to benefit by any advantages in tariff or otherwise, which the Marconi Company may offer, and who is willing to run the risk of his message getting lost on the way, or read by Mr. Maskelyne at Porthcurnow, should be denied the necessary facilities? Or is it any reason why the more enlightened Governments of Canada and the Lnited States should be penalised by having their messages delayed, as we suppose must now occur if they arrive by night?

It seems to us that the correct thing for the Post Office to do is to grant the Wircless Telegraph Co. the facilities for which it asks without delay, lest the Post Office be accused, with some justice, of blocking the progress of an enterprise of great promise. Whether Transatlantic wireless telegraphy will prove of commercial value or not time will show; the shareholders may be relied upon to put an end to it soon enough if it neither pays nor gives prospect of paying. Should it, as some sanguine people think, prove better than the submarine cable, and ultimately supplant it, the cable companies will have to suffer that the world at large may gain; it will not be the first time in history that the old order has given place to the new. But none of these questions, commercial or technical, secms to us to be the concern of the Post Office, which should only desire to facilitate a new means of communication in which, rightly or wrongly, a large portion of the general public have considerable confidence.

In the meantime, the development of wireless telegraphy progresses rapidly in other directions, and especially in the direction in which we have always maintained it would be most serviceable, namely, in increasing the safety and relieving the monotony of travelling by sea. Reports are continually appearing in the papers of ships communicating with one another, or with the shore, for sone time prior to their arrival. Reuter's Agency has been experimenting in transmitting news to ships, and last week the Minneapolis, thirty-six hours before its arrival, was put in possession of all the latest news, much to the satisfaction of the passengers. Reuter's Agency, it is said, looks forward to the time when it will be able to maintain a daily news service right across the Atlantic. The day is possibly not far distant when it will be possible for all ships to keep in constant communication with land. and if this result is attained, wireless telegraphy will have scored a great and lasting success; but to derive the greatest benefit from such an achievement in this, as in the Transatlantic service, the Post Office must cooperate and not oppose progress. We trust someone will ask Mr. Ballour if it is the intention of the Government to bar all scientific progress.

MaLrice Solomon.

\section{THE CONSTITUTION OF THE NEW EDUCATION COMMITTEES.}

VARIOUS applications have been made to the Board of Education for suggestions with respect tn the constitution of education committees under the new Education Act, and the framing of schemes for the purpose. With a view to assist councils who have not as yet framed schemes for themselves and desire assistance, the Board of Education issued on February I 2 a memorandum making suggestions as to the main matters which should be provided for by the scheme. The Act itself lays it down that every scheme shall provide for the appointment by the council of at least a majority of the committee, and the persons so appointed shall be persons who are members of the council, unless, in the case of a county, the council shall otherwise determine; for the appointment by the council, on the nomination or recommendation, where it appears desirable, of other bodies (including associations of voluntary schools), or persons of experience iil education, and of persons acquainted with the needs of the various kinds of schools in the area for which the council acts; for the inclusion of women, as well as men, among the members of the committee; and for the appointment, if desirable, of members of school boards existing at the time of the passing of the Education Act as members of the first committee.

The memorandum referred to contains a model scheme, which goes a long way towards elucidating what, in the opinion of the Board of Education, is to be understood exactly by the words " nomination or recommendation " in the Act. This part of the model scheme reads as follows:-

Nominated members, one nominated by each of the following bodies, e.g.:--

The

council of the University of

Recommended members, one recommended by each of the following bodies, e.g. :-

The Chamber of Conmerce of

The Agricultural Society of

The Association of

The Governing Body of the

An electing body consisting of

Members appointed after consultation with :- -

The

It is of great importance that the Board of Education appears to contemplate that the right of nomination will belong to universities alone, while other associations and institutions can merely recommend persons for appointment by the council. Moreover, the memorandum refers to the representation of the interests of University education, and as we believe this is the first time in which the work of Universities has been mentioned as coming within the sphere of the Act, it is important to direct particular attention to this point. 